\title{
HUBUNGAN DUKUNGAN KELUARGA DENGAN AKTIFITAS SEHARI-HARI PASIEN GAGAL GINJAL KRONIK YANG MENGALAMI HEMODIALISA DI RSU IPI MEDAN TAHUN 2018
}

\author{
${ }^{1}$ Deddy Sepadha Putra Sagala, ${ }^{2}$ Maria Ruth Annike Sitompul \\ ${ }^{1}$ Dosen Prodi S1Keperawatan, STIKes Imelda, Jalan Bilal Nomor 52 Medan; \\ ${ }^{2}$ Alumni STIKes Imelda \\ Email: '1deddyspsagala@gmail.com, 2.mariarasitompul@gmail.com
}

\begin{abstract}
ABSTRAK
Gagal ginjal kronis merupakan suatu penyakit ginjal tahap akhir yang mengakibatkan gangguan fungsi ginjal yang bersifat irreversible dan menahun sehingga terjadinya penurunan kemampuan fungsi tubuh untuk mempertahankan metabolisme serta keseimbangan cairan dan elektrolit. Pasien gagal ginjal kronis akan mengalami kehilangan fungsi ginjal sampai $90 \%$ atau lebih, sehingga kemampuan tubuh untuk mempertahankan cairan dan elektorilit terganggu, sekresi menjadi tidak adequat dan fungsi hormonal terganggu sehingga mengakibatkan sindrom uremia atau azotemi (Rendy \& Margareth, 2012 ; Parson, Toffelmire \& Valack, 2006).Jenis penelitian ini kuantitatif menggunakan desain korelasional dengan jenis rancangan penelitian cross sectional. Dimana jumlah populasi sebanyak 98 responden, metodepengambilan sampel probability samplingtehnik purposive sampling sampel, besar sampel ditetapkan menggunakan rumus slovin didapati responden penelitian ini sebanyak 79 penderita gagal ginjal kronik yang menjalani terapi hemodialisa di RSU Imelda Medan Tahun 2018. Pengumpulan data menggunakan Instrumen dukungan keluarga (Berlin Social Support Scale (BSSS)) sejumlah 16 pertanyaan dan aktifitas sehari-hari Curtin \& Mapes (2005) : Cook \& Jassal (2008) sejumlah 38 pertanyaan, Tehnik pengukuran pertanyaan masing-masing menggunakan skala Linkert dalam bentuk kuesioner tertutup. Pengolahan data mengguanakan analisa data univariat dan bivariatmenggunakan uji statistik parametrik yaitu uji pearson corelation (pearson product moment) dengan $p<0.05$, didapati hasil penelitian menunjukkan nilai probabilitas $(p)$ untuk dukungan keluarga $=0.000$, yang berarti ada hubungan secara signifikan dengan aktifitas sehari-hari $(p<0.05)$. Hasil analisis diperoleh nilai correlation coefficient $(r)=0,835$, menunjukkan hubungan sangat kuat dan berpola positif artinya semakin tinggi dukungan keluarga yang diterima maka aktifitas sehari-hari yang dimiliki pasien gagal ginjal kronis yang menjalani hemodialisa semakin baik.
\end{abstract}

Kata kunci : Dukungan keluarga, Aktifitas sehari-hari, gagal ginjal kronik, hemodialisa.

\section{PENDAHULUAN}

Penyakit gagal ginjal kronis merupakan masalah kesehatan yang berkembang pesat. Diperkirakan sekitar $11 \%$ atau 19,2 juta orang penduduk Amerika Serikat mengalami gagal ginjal kronik (Black \& Hawks, 2009). Gagal ginjal kronis merupakan ancaman global terhadap populasi secara umum, khususnya bagi negara-negara berkembang. Menurut data WHO tahun 2011 memperkirakan secara global bahwa penyakit gagal ginjal kronis merupakan penyebab utama kematian diurutan ke-12 dan urutan ke 17 penyebab kecacatan (Zachariah \& Gopalkrishnan, 2014).

Smeltzer dan Bare (2002), menyatakan bahwa untuk mengatasi masalah gagal ginjal kronis dapat dilakukan berbagai terapi, salah satunya yaitu dengan terapi hemodialisis. Hemodialisis merupakan tindakan untuk mengganti sebagian fungsi dari ginjal. Pasien gagal ginjal kronik yang melakukan terapi hemodialisis di dunia diperkirakan berjumlah sekitar 1,4 juta orang dengan insidensi pertumbuhan $8 \%$ per tahun (WHO,2013). Di indonesia, berdasarkan data Indonesia Renal Registry jumlah pasien di unit hemodialisis tahun 2012 sekitar 19621 orang pasien baru dan pasien aktif sebanyak 9161 orang.

Pasien gagal ginjal kronis dengan hemodialisa memiliki masalah perawatan diri (self care deficit) yang berdampak terhadap kemampuan penderita untuk melakukan pemenuhan kebutuhan aktivitassehari-hari. Gangguan perawatan diri (self care) yang umum dialami oleh pasien hemodialisa adalah perawatan diri sehari- 
hari (self care activity), seperti, kemampuan perawatan fisik, pemenuhan asupan cairan dan nutrisi, regiment terapi pengobatan, perawatan akses vaskular, kemampuan berinteraksi, pemanfaatan fasilitas kesehatan, melaporkan gejala yang muncul dan juga perilaku kesehatan. Gangguan perawatan diri sehari-hari tersebut akan dapat berdampak terhadap pemenuhan kemapuan aktivitas sehari-hari pasien

Hemodialisa, seperti: makan dan minum, mandi, berpakaian, berdandan, kebersihan diri, toileting, dan mobilitas (Curtin \& Mapes, 2005 : Cook \& Jassal, 2008). Heidizadeh, Jaliazar dan Athaspheikar (2011), mengatakan bahwa ketidakmampuan pasien hemodialisa melakukan perawatan diri akan berdampak terhadap kemampuan melakukan aktivitas sehari-hari serta gangguan terhadap kualitas hidup.

Pasien yang menjalani terapi hemodialisa akan mengalami gangguan dalam pemenuhan kebutuhan perawatan diri sehari-hari akibat ketakutan yang dialami dalam melakukan kegiatan aktivitas seharihari yang berlebih, hal ini terjadi akibat minimnya informasi yang diperoleh dari petugas kesehatan selama menjalani proses terapi. Kemampuan perawatan diri pasien kronis (seperti: pasien hemodialisa) sudah menjadi perhatian di dunia. Salah satu penyebab hal tersebut adalah kurangnya pengetahuan pasien terkait dengan penyakit dan terapi yang dijalaninya, hal ini dapat terjadi akibat kurangnya peran andil dari petugas kesehatan dalam memberikan pengetahuan atau edukasi terhadap keluarga dan pasien tersebut (Taylor \& Renpenning, 2011).

Menurut Notoadmodjo (2007), peran pendidikan kesehatan seperti bimbingan dan penyuluhan merupakan salah satu upaya yang dapat mengubah prilaku individu untuk tetap mempertahankan status kesehatnannya. Thornton dan Lingertfelt (2011) mengatakan bahwa edukasi perawatan diri (self care) secara signifikan dapat meningkatkan pengetahuan dan kemandirian serta meningkatkan kemampuan pasien dalam melakukan perawatan sehari-hari di rumah, seprti: manajemen diri untuk pemenuhan kebutuhan nutrisi dan mengikuti program terapi pengobatan.
Cook dan Jassal (2008), dalam penelitiannya, mengatakan bahwa dari 168 responden yang diteliti, responden yang mengalami ketergantungan terhadap pekerjaan rumah tangga (80\%), belanja (81\%), mencuci $(80 \%)$, memasak $(68 \%)$, menaiki tangga (52\%), mandi (68\%), transportasi (49\%) dan ambulasi atau pergerakan (29\%). Pasien hemodialisa yang mengalami gangguan kebutuhan aktivitas sehari-hari akan berdampak terhadap kestabilan emosi dan relasi sosial yang dapat mempengaruhi beban pikiran penderita. Keterbatasan aktivitas sehari-hari pasien hemodialisa juga dapat mengakibatkan terjadinya stress, frustasi, berkurangnya daya ingat, mudah tersinggung serta perasaan sensitif dan frustasi (Rulli dan Roesli, 2001).

Gomes, Roberedo, Carvalho, Teixeirca, Filho, Oliveira, Chebli, et.al (2015), mengatakan bahwa aktifitas fisik pasien gagal ginjal kronis yang menjalani hemodialisa akan lebih buruk, akibat efek samping yang terjadi dari terapi, seperti: anemia, uremia, miopati, gangguan tulang dan mineral, gangguan cardiovaskular serta gangguan psikologis seperti depresi, yang akan berdampak terhadap kemampuan pasien untuk melakukan kebutuhan aktivitas sehari-hari, seperti kebutuhan mobilisasi, Kebutuhan aktivitas mobilisasi yang tidak terpenuhi dapat menjadi salah satu faktor penyebab kematian. Domarco et al (2012), mengatakan bahwa pasien hemodialisa yang mengalami gangguan pemenuhan kebutuhan aktivitas sehari-hari akan berdampak tehadap penurunan status kesehatan secara fisik, mengakibatkan perlunya perawatan jangka panjang serta peningkatan pearawatan berulang ke rumah sakit yang dapat memciu terjadinya peningkatan pengeluaran biaya perawatan.

Berdasarkan wawancara yang dilakukan oleh peneliti pada bulan maret tahun 2016 terhadap salah seorang perawat di RSU Imelda Medan menyatakan bahwa pasien gagal ginjal kronis yang menjalani hemodialisa tahun 2016 sebanyak 30 orang, beberapa diantaranya mengalami keterbatasan kemampuan dalam melakukan perawatan dirinya sehari-hari, seperti pasien takut untuk berjalan ke ruang unit hmeodialisa pada saat mau melakukan terapi meskipun edukasi sudah diberikan sebelumnya, namun edukasi tersebut belum 
terrealisasikan dengan baik, hal ini disebabkan oleh edukasi terhadap pasien hemodialisa belum menjadi bagian dari prosedur operasional yang sudah ditetapkan semestinya.

Berdasarkan uraian tersebut peneliti tertarik meneliti tentang Hubungan Dukungan Keluarga Dengan Aktifitas Sehari-Hari Pasien Gagal Ginjal Kronik Yang Mengalami Hemodialisa Di RSU IPI Medan Tahun 2018.

\section{Perumusan Masalah}

Penyakit gagal ginjal kronis merupakan suatu gangguan dalam tubuh yang mengakibatkan gagalnya fungsi tubuh untuk membuang sisa metabolisme yang sudah tidak dibutuhkan lagi yang mengakibatkan terjadinya penimbunan racun atau sering disebut sindrome uremia. Salah satu upaya yang dapat diberikan untuk membantu pembuangan sisa metabolisme tersebut harus menjalani proses terapi pengobatan dialisis atau hemodialisa, namun program terapi hemodialisa akan dijalani seumur hidup dan akan dapat berdampak terhadap gangguan tubuh salah satunya terjadinya ketergantungan terhadap orang lain dalam memenuhi kebutuhan aktivitas sehariharinya akibat dari program serta komplikasi yang terjadi, seperti kelemahan dan gangguan psikologis atau ansietas yang berdampak terhadap kurangnya motivasi dalam diri untuk meningkatkan kemampuan terhadap perawatan diri (self care).

Perawatan diri (Self care) pada pasien gagal ginjal merupakan upaya pasien secara aktif untuk mempertahankan kesehatan dan berespon terhadap aktivitas sehari hari yang akan dilakukannya. Program perawatan diri (self care) ini mampu meningkatkan kualitas hidup terkait aktivitas sehari-hari pasien gagal ginjal kronis. Namun kenyataan yang ditemui masih tingginya kejadian rehospitalisasi pasien dan ketidakmampuan pasien melakukan aktivitas sehari hari akibat kurangnya dorongan dan pengetahuan terkait dengan penyakit dan gangguan psikologis yang dialami, hal tersebut disebabkan karena pasien belum mengikuti dengan benar upaya pelaksanaan perawatan diri, yaitu edukasi perawatan diri.

Tujuan Penelitian
1. Tujuan umum yaitu untuk mengidentifikasi Hubungan Dukungan Keluarga Dengan Aktifitas Sehari-Hari Pasien Gagal Ginjal Kronik Yang Mengalami Hemodialisa Di RSU IPI Medan Tahun 2018.

2. Tujuan khusus yaitu meliputi :

1) Mengidentifikasi Dukungan Keluarga Pasien Gagal Ginjal Kronik Yang Mengalami Hemodialisa,

2) Mengidentifikasi Aktifitas SehariHari Pasien Gagal Ginjal Kronik Yang Mengalami Hemodialisa,

3) Mengidentifikasi Hubungan Dukungan Keluarga Dengan Aktifitas Sehari-Hari Pasien Gagal Ginjal Kronik Yang Mengalami Hemodialisa.

\section{Hipotesis}

1. Ada Hubungan Dukungan Keluarga Dengan Aktifitas Sehari-Hari Pasien Gagal Ginjal Kronik Yang Mengalami Hemodialisa,

2. Tidak ada Hubungan Dukungan Keluarga Dengan Aktifitas Sehari-Hari Pasien Gagal Ginjal Kronik Yang Mengalami Hemodialisa.

\section{METODE}

Jenis penelitian ini merupakan penelitian kuantitatif menggunakan desain korelasional dengan jenis rancangan penelitian cross sectional. Lokasi dan Waktu Penelitian Penelitian ini akan dilaksanakan di Rumah Sakit Umum Imelda Medan. Pengambilan data dilaksanakan pada bulan Juli 2018. Populasi dalam penelitian ini adalah seluruh penderita gagal ginjal kronik yang menjalani terapi hemodialisa berjumlah 98 orang di Rumah Sakit Umum Imelda Medan. Teknik sampling yang digunakan dalam penelitian ini dengan menggunakan metode purposive sampling maka didapatkan jumlah sampel yang digunakan dalam penelitian ini sebanyak 79 responden.

Instrumen pengukuran data dalam penelitian ini menggunakan kuesioner terstruktur yang dikembangkan berdasarkan komponen variabel dukungankeluarga (Berlin Social Support Scale (BSSS)) dan Kuesioner penilaian aktifitas sehari-hari 
Curtin \& Mapes (2005) : Cook \& Jassal (2008)

\section{PEMBAHASAN}

\section{Analisis Univariat}

Tabel 1. Karakteristik Pasien Gagal Ginjal Kronis yang Menjalani Hemodialisa
Berdasarkan Usia, Jenis Kelamin, Pendidikan, Status Pernikahan, Suku Bangsa, Status Pekerjaan, Penghasilan Keluarga, Biaya Pengobatan, Lama Menjalani Hemodialisa, dan Siklus Hemodialisa di RSU Imelda Pekerja Indonesia Medan Tahun $2018 \quad(n=79)$.

\begin{tabular}{|c|c|c|c|c|c|c|}
\hline \multirow{2}{*}{ No } & \multirow{2}{*}{ Karakteristik } & \multirow{2}{*}{ Frekuensi } & \multirow{2}{*}{ Persentase $(\%)$} & \multicolumn{3}{|c|}{ Aktifitas Sehari-Hari } \\
\hline & & & & Baik $(\%)$ & Cukup (\%) & Buruk (\%) \\
\hline \multirow{4}{*}{1} & Usia (Tahun) & & & & & \\
\hline & 26-44 (usia dewasa) & 9 & 11,4 & $2(22,2)$ & $5(55,6)$ & $2(22,2)$ \\
\hline & 45-59 (usia pertengahan) & 48 & 60,8 & $14(29,2)$ & $27(56,2)$ & $7(14,6)$ \\
\hline & 60-74 (lanjut usia) & 22 & 27,8 & $4(18,2)$ & $12(54,5)$ & $6(27,3)$ \\
\hline \multirow{3}{*}{2} & Jenis Kelamin & & & & & \\
\hline & Laki-laki & 25 & 31,6 & $9(36,0)$ & $13(52,0)$ & $3(12,0)$ \\
\hline & Perempuan & 54 & 68,4 & $11(20,4)$ & $31(57,4)$ & $12(22,2)$ \\
\hline \multirow{5}{*}{3} & Pendidikan & & & & & \\
\hline & SD & 22 & 27,8 & $2(9,0)$ & $10(45,5)$ & $10(45,5)$ \\
\hline & SMP & 18 & 22,8 & $5(27,8)$ & $12(66,7)$ & $1(5,6)$ \\
\hline & SMA & 36 & 45,6 & $11(30,6)$ & $21(58,3)$ & $4(11,1)$ \\
\hline & PT & 3 & 3,8 & $2(66,7)$ & $1(33,3)$ & $0(0)$ \\
\hline \multirow{4}{*}{4} & Status Pernikahan & & & & & \\
\hline & Menikah & 59 & 74,7 & $18(30,5)$ & $33(55,9)$ & $8(13,6)$ \\
\hline & Janda/Duda & 16 & 20,3 & $2(12,5)$ & $7(43,8)$ & $7(43,8)$ \\
\hline & Belum Menikah & 4 & 5,1 & $0(0)$ & $4(100)$ & $0(0)$ \\
\hline \multirow{4}{*}{5} & Suku Bangsa & & & & & \\
\hline & Batak & 41 & 51,9 & $9(22,0)$ & $22(53,7)$ & $10(24,4)$ \\
\hline & Jawa & 32 & 40,5 & $9(28,1)$ & $19(59,4)$ & $4(12,5)$ \\
\hline & Melayu & 6 & 7,6 & $2(33,3)$ & $3(50,0)$ & $1(16,7)$ \\
\hline \multirow{3}{*}{6} & Status Pekerjaan & & & & & \\
\hline & Bekerja & 36 & 45,6 & $12(33,3)$ & $18(50,0)$ & $6(16,7)$ \\
\hline & Tidak bekerja & 43 & 54,4 & $8(18,6)$ & $26(60,5)$ & $9(20,9)$ \\
\hline \multirow{3}{*}{7} & Penghasilan Keluarga & & & & & \\
\hline & $\leq \mathrm{Rp} 2.750 .000(\leq \mathrm{UMK})$ & 66 & 83,5 & $15(22,7)$ & $36(54,6)$ & $15(22,7)$ \\
\hline & $>\operatorname{Rp} 2.750 .000(>\mathrm{UMK})$ & 13 & 16,5 & $5(38,5)$ & $8(61,5)$ & $0(0)$ \\
\hline \multirow{6}{*}{8} & Biaya Pengobatan & & & 2 & & \\
\hline & BPJS & 76 & 96,2 & $19(25,0)$ & $42(55,3)$ & $15(19,7)$ \\
\hline & Asuransi Lain & 3 & 3,8 & $1(33,3)$ & $2(66,7)$ & $0(0)$ \\
\hline & $\begin{array}{c}\text { Lama Menjalani } \\
\text { Hemodialisa }\end{array}$ & & & & & \\
\hline & 3-6 Bulan & 56 & 70,9 & $14(25,0)$ & $30(53,6)$ & $12(21,4)$ \\
\hline & $>6-12$ Bulan & 23 & 29,1 & $6(26,1)$ & $14(60,9)$ & $3(13,0)$ \\
\hline \multirow{5}{*}{10} & Siklus Hemodialisa & & & & & \\
\hline & $2 \mathrm{X}$ perminggu & 55 & 69,7 & $15(27,2)$ & $31(56,4)$ & $9(16,4)$ \\
\hline & $3 \mathrm{X}$ perminggu & 22 & 27,8 & $4(18,2)$ & $12(54,5)$ & $6(27,3)$ \\
\hline & $4 \mathrm{X}$ perminggu & 2 & 2,5 & $1(50,0)$ & $1(50,0)$ & $0(0)$ \\
\hline & Total & 79 & 100 & $20(25,3)$ & $44(55,7)$ & $15(19,0)$ \\
\hline
\end{tabular}

\section{Variabel Dukungan Keluarga}

Tabel 2. Distribusi Frekuensi dukungan keluarga dengan aktifitas sehari-hari di RSU Imelda Pekerja Indonesia Medan Tahun 2018 ( $\mathrm{n}=79)$

\begin{tabular}{cccccc}
\hline \multirow{2}{*}{ Dukungan Keluarga } & \multirow{2}{*}{ F } & \multirow{2}{*}{ Persentase (\%) } & \multicolumn{3}{c}{ Aktifitas Sehari-hari } \\
\cline { 4 - 6 } & & & Baik (\%) & Cukup (\%) & Buruk (\%) \\
\hline Kuat & 20 & 25,3 & $18(90,0)$ & $1(5,0)$ & $1(5,0)$ \\
\hline Sedang & 47 & 59,5 & $1(2,1)$ & $43(91,5)$ & $3(6,4)$ \\
\hline Lemah & 12 & 15,2 & $1(8,3)$ & $0(0)$ & $11(91,7)$ \\
\hline Total & 79 & 100 & $20(25,3)$ & $44(55,7)$ & $15(19,0)$ \\
\hline
\end{tabular}


Tabel 2 menunjukkan bahwa dari 79 pasien gagal ginjal kronis yang menjalani hemodialisa lebih dari setengah menerima dukungan keluarga pada kategori sedang sebanyak 47 orang $(59,5 \%)$ dan sebagian besar aktifitas sehari-harinya cukup sebanyak 43 orang $(91,5 \%)$, seperempat menerima dukungan keluarga pada kategori kuat sebanyak 20 orang $(25,3 \%)$ dan sebagian besar aktifitas sehari-harinya baik sebanyak 18 orang $(90,0 \%)$, dan hampir seperempat menerima motivasi pada kategori lemah sebanyak 12 orang $(15,2 \%)$ dan sebagian besar aktifitas sehari-harinya buruk sebanyak 11 orang $(91,7 \%)$.

\section{VariabelAktifitas Sehari-Hari}

Tabel 3. Distribusi Frekuensi aktifitas Sehari-Hari Pasien Gagal Ginjal Kronis Yang Menjalani Hemodialisa di RSU Imelda Pekerja Indonesia Medan Tahun $2018(n=79)$

\begin{tabular}{ccc}
\hline Aktifitas Sehari-Hari & F & $(\boldsymbol{\%})$ \\
\hline Baik & 20 & 25,3 \\
\hline Cukup & 44 & 55,7 \\
\hline Buruk & 15 & 19,0 \\
\hline Total & 79 & 100 \\
\hline
\end{tabular}

Tabel 3 menunjukkan bahwa dari 79 pasien gagal ginjal kronis yang menjalani hemodialisa lebih dari setengah aktifitas sehari-harinyacukup sebanyak 44 orang $(55,7 \%)$, seperempat aktifitas sehariharinyabaik sebanyak 20 orang (25,3\%), dan aktifitas sehari-harinyaburuk sebanyak 15 orang $(19,0 \%)$.

\section{Analisis Bivariat}

Berdasarkan hasil uji normalitas dengan menggunakan perbandingan nilai skewness dan standar error menghasilkan skor $<2$ dan Kolmogrov Smirnov Test menghasilkan $p>0,05$ yang berarti distribusi data variabel dukungan keluarga dan aktifitas sehari-hari berdistribusi normal, sehingga uji statistik pada analisis bivariat yang digunakan yaitu uji pearson corelation (pearson product moment).

\section{Hasil uji statistik untuk hubungan dukungan keluarga dengan aktifitas sehari-hari di RSUImelda Pekerja Indonesia Medan.}

Tabel 4 . Hasil Uji Pearson Corelation Dukungan Keluarga Dengan Aktifitas Sehari-Hari Pasien Gagal Ginjal Kronis
Yang Menjalani Hemodialisa di RSU Imelda Pekerja Indonesia Medan Tahun $2018(n=79)$.

\begin{tabular}{ccc}
\hline \multirow{2}{*}{ Variabel } & \multicolumn{2}{c}{ Aktifitas Sehari-hari } \\
\cline { 2 - 3 } & $\mathbf{r}$ & $\boldsymbol{p}$ \\
\hline $\begin{array}{c}\text { Dukungan } \\
\text { Keluarga }\end{array}$ & 0,835 & 0,000 \\
\hline
\end{tabular}

Tabel 4 menunjukkan nilai probabilitas $(p)$ untuk dukungan keluarga $=0.000$, yang berarti ada hubungan secara signifikan dengan aktifitas sehari-hari $(p<0.05)$. Hasil analisis diperoleh nilai correlation coefficient $(\mathrm{r})=0,835$, menunjukkan hubungan sangat kuat dan berpola positif artinya semakin tinggi dukungan keluarga yang diterima maka aktifitas sehari-hari yang dimiliki pasien gagal ginjal kronis yang menjalani hemodialisa semakin baik.

\section{KESIMPULAN}

Berdasarkan data yang diperoleh dari 79 pasien gagalginjalkronis yang menjalani hemodialisadi RSU Imelda Medan :

1. Dukungan keluarga pasien gagal ginjal yang menjalani hemodialisa di RSU Imelda Medan.

Menurut asumsi peneliti dukungan keluarga responden dalam kategori sedang dengan aktifitas sehari-harinya yang cukup dikaitkan dengan karakteristik responden usia rata-rata responden mayoritas 45-59 (usia pertengahan) 48 responden $(60,8 \%)$, Hal ini sejalan dengan penelitian Desitasari (2014) didapatkan responden yang menderita penyakit gagal ginjal kronik yang banyak dari usia 40-60. Alam dan Hadibroto (2007) menyatakan bahwa semakin bertambahnya usia, fungsi ginjal juga akan menurun. Setelah umur 40 tahun akan terjadi kehilangan beberapa nefron. Setiap dekade pertambahan umur, fungsi ginjal menurun sekitar $10 \mathrm{ml} / \mathrm{menit} / 1,73 \mathrm{~m} 2$ - Selain karena penurunan fungsi ginjal organ tubuh oleh pertambahan usia, hal ini juga dapat disebabkan oleh beragam penyakit yang muncul di usia lanjut yang menimbulkan komplikasi pada sistem urinaris (Katzung, 2002).

Berdasarkan tingkat pendidikan responden PT hanya 3 responden $(3,8 \%)$ Hal ini sejalan dengan penelitian Ismail, Hasanuddin dan Bahar (2011) yang menunjukkan bahwa mayoritas responden berpendidikan Menengah (SMP dan SMA) 
yaitu sebanyak 68,6\%. Penderita gagal ginjal kronik yang memiliki pendidikan yang tinggi akan mempunyai pengetahuan yang luas. Hal ini memungkinkan penderita untuk dapat mengontrol dirinya dalam mengatasi masalah yang dihadapi, mempunyai rasa percaya diri yang tinggi, berpengalaman, dan mempunyai perkiraan yang tepat untuk mengatasi kejadian, mudah mengerti tentang apa yang dianjurkan oleh petugas kesehatan (Yuliaw, 2009). Individu yang berpendidikan sarjana, perilakunya akan berbeda dengan individu yang berpendidikan SD. Niven (2012) menyatakan pendidikan pasien dapat meningkatkan kepatuhan, sepanjang pendidikan tersebut merupakan pendidikan yang aktif.

\section{Variabelaktifitas sehari-hari pasien gagal ginjal yang menjalani hemodialisa di RSU Imelda Medan}

Hasi penelitian menunjukkan bahwa dari 79 pasien gagal ginjal kronis yang menjalani hemodialisa lebih dari setengah aktifitas sehari-harinyacukup sebanyak 44 orang $(55,7 \%)$, seperempat aktifitas sehariharinya baik sebanyak 20 orang $(25,3 \%)$, dan aktifitas sehari-harinya buruk sebanyak 15 orang $(19,0 \%)$. Menurut Sathvik, parthasarathi, Narahari \&Gurudev (2008), aktifitas sehari-hari menjadi ukuran penting setelah pasien menjalani terapi penggantian ginjal seperti hemodialisis atau transplantasi ginjal. Aktifitassehari-hari pasien yang menjalani hemodialisis semakin menurun karena pasien tidak hanya menghadapi masalah kesehatan yang terkait dengan penyakit ginjal kronik tetapi juga terkait dengan terapi yang berlangsung seumur hidup, akibatnya aktifitas sehari-hari pasien yang menjalani hemodialisis lebih menurun (Mittal, S.K., Ahern, L., Flaster, E., Maesaka, J.K., \& Fishbane, S., 2001). Cleary(2005).

\section{Hubungan dukungan keluarga dengan aktifitas sehari-hari pasien gagal ginjal yang menjalani hemodialisa di RSU Imelda Pekerja Indonesia Medan.}

Hasil penelitian pada 79 pasien gagal ginjal kronis yang menjalani hemodialisa berdasarkan uji pearson corelation terdapat pada tabel 4.6 di atas menunjukkan nilai probabilitas $(p)$ untuk dukungan keluarga $=$ 0.000 , yang berarti ada hubungan secara signifikan dengan aktifitas sehari-hari $(p<0.05)$. Hasil analisis diperoleh nilai correlation coefficient $(\mathrm{r})=0,835$, menunjukkan hubungan sangat kuat dan berpola positif artinya semakin tinggi dukungan keluarga yang diterima maka aktifitas sehar-hari yang dipenuhi pasien gagal ginjal kronis yang menjalani hemodialisa semakin baik.

Dukungan keluarga dapat menjadi faktor yang sangat berpengaruh dan menentukan keyakinan dan nilai kesehatan individu dan dapat juga menentukan tentang program pengobatan yang diterima. Niven (2002) menyatakan bahwa dukungan keluarga merupakan salah satu faktor yang mempengaruhi ketidakpatuhan dalam menjalani hemodialisa. Dari hasil penelitian yang telah dilakukan Togatorop (2011) yang menyatakan bahwa dukungan keluarga pasien GGK dalam kategori positif sebesar $62,5 \%$ (20 orang) dan kategori negatif sebesar $37,5 \%$ ( 12 orang). Hal ini secara tidak langsung mengungkapkan bahwa dukungan keluarga pasien dipengaruhi oleh berbagai multidimensi hidup yang sangat luas seperti, kesehatan fisik, keadaan psikologis, tingkat kemandirian, hubungan sosial (dukungan sosial), keyakinan pribadi, dan status sosial ekonomi (CDC, 2011). Peneliti berasumsi bahwa pasien yang memeiliki keyakinan, harapan dan keingian yang kuat bisa menumbuhkan dukungan keluarga yang positif pemberian edukasi pada pasien gagal ginjal kronik yang dilakukan terapi hemodialisa agar pasien dapat menjalani terapi sesuai jadwal.

\section{SARAN}

\section{BagiPelayananKesehatan}

Hasil penelitian ini diharapkan dapat digunakan sebagai masukan bagi tenaga kesehatan untuk memberikan pendidikan kesehatan kepada keluarga tentang pentingnya kunjungan terapi hemodialisa secara rutin bagi pasien gagal ginjal kronik yang sedang menjalani terapi hemodialisa untuk menurunkan tingkat keparahan penyakit yang dialami pasien, sehingga klien mendapatkan dukungan dari keluargai untuk rutin menjalani terapi dan dapat 
meningkatkan pemenuhan aktifitas sehariharinya.

\section{BagiPendidikanKeperawatan}

Hasil penelitian ini dapat dijadikan tambahan informasi yang berhubungan dengan hubungan dukungan keluarga dengan aktifitas sehari-hari pada pasien gagal ginjal kronis yang sedang menjalani pengobatan terapi hemodialisa.

\section{BagiPenelitiSelanjutnya}

Diharapkan dapat dilakukan penelitian lanjutan dengan menggunakan metode penelitian kualitatif untuk mengeksplorasi hubungan dukungan keluarga dengan aktifitas sehari-hari pada pasien gagal ginjal kronis yang sedang menjalani pengobatan terpi hemodialisa sehingga dapat melengkapi hasilpenelitian yang telah ada.

\section{DAFTAR PUSTAKA}

Black \& Hawks. (2009). Medical surgical nursing clinical management for positive outcomes. $7^{\text {th }}$ Ed. St.Louis: Missouri Elseveir Saunders.

Badan Penyelenggara Jaminan Kesehatan. (2014). Panduan praktis prolanis (program pengelolaan penyakit kronis). Jakarta: BPJS.

Brunner \& Suddarth. (2001). Keperawatan medikal bedah. (ed. 8. vol.1-2). Jakarta: EGC.

Da Silva, R.A.R., De Souza, V.L., De Oliveira, G.J.N., Da Silva, B.C.O., Rocha, C.C.T., \& Holanda, J.R.R. (2016). Coping strategies used by chronic renal failure patients on hemodialysis. Escola Anna Nery 20(1) Jan-Mar 2016. Doi: 10.5935/14148145.20160020. Diakses tanggal 20 Juni 2018.

Fain, J.A. (2009). Reading, understanding and apliying nursing research. 3 th ed. Philadelphia, FA.: Davis Company.

Ferrans, C. F. (1996). Development of a conceptual model of quality of life. An International Journal, 10(3), 293 304.

Folkman, S. (1985). Ways of coping questionare. University of California : San fransisko. Diakses dari http://caps.ucsf.edu/uploads/tools/surv eys/ways\%20coping.pdf. Pada tanggal 04 Maret 2018.

Garousi, S \& Garrusi, B. (2013). Does perceived family support has a relation with depression and anxiety in an iranian diabetic sample. International Journal of Caring Science SeptemberDecember 2013 Vol 6 Issue 3. Diakses tanggal 25 Juni 2018.

Hays R.D., Kallich J.D., Mapes D.L., Coons S.J., Amin N., Carter W.B., \& Kamberg C. (1997). Kidney disease quality of life short form (KDQOLSFtm), version 1.3: A manual for use and scoring. Santa Monica, CA: RAND Health.

Ibrahim Kusman, Taboonpong, S., \& Nilmanat. (2009). Coping and quality of life among indonesians undergoing hemodialysis. Vol. 13(2). Thai Journal of Nursing Research, 13(2) 109-117.

Ignatavicius, D., \& Workman, M.L. (2013). Medical surgical nursing: Patientcentered collaborative care. (Edisi 7). Elsevier Saunders.

Kaltsouda, A., et al. (2011). Defensive coping and health-related quality of life in chronic kidney disease: A cross sectional stud. BMC Nephrology, 12(28), 1-9.

Kohlsdorf Marina. (2015). Coping strategies adopted by patients with chronic kidney disease in preparation for transplant. Psychology, Community \& Health, 4(1). doi:10.5964/pch.v4i1.103.

Mc. Cann, K \& Boore, J. R. P. (2000). Fatique in person with renal failure who require maintenance hemodialysis. Journal of Advance Nursing, 32(5).

Muhamad, M., \&Afshari, M., \& Kazilan, F. (2011). Family support in chronic kidney disease. Asian Pacific Journal Care Prev,12, 1389-1397. Diakses tanggal 25Juni 2018.

Narjes Khalili., et al. (2013). Coping strategies, quality of life and pain in women with breast cancer. Iranian Journal of Nursing and Midwifery Research, 18(2): 105-111.

Panthee, B., Kritpracha, C., \& Chinnawong, T., (2011). Correlation between Coping Strategies and Quality of Life among Myocardial Infarction Patients 
in Nepal. Nurse Media Journal of Nursing, 1(2), 187-194.

Polit, D.F., \& Beck, C.T. (2012). Nursing research: Generation and assesing evidance for nursing practice. (9 th. Ed.). Philadelphia, F.A.: Lippincott Williams \& Wilkins.

Sadeghi H., Saeedi M., Rahzani K., \& Espandiary. (2015). The relationship between social support and death anxiety in hemodialysis patients. Iranian Journal of Psychiatric Nursing, 2(8).

Sarafino, P.E., \& Smith, W.T., (2011). Health psychology ; Biopsychosocial Interaction. (7 th ed.). Wiley.

Schatell, M.S., \& Stec, P. (2008). How understanding motivation can improve dialysis practices.Nephrology News \& Issue. Diakses dari www.nephronline.com pada tanggal 19 Agustus 2018.

Son, Y.J., Cloi, K.Y., Park, Y.R., \& Bae, J.L. (2009). Depression, symptoms and the quality of life patients on hemodialysis for life patients on hemodialysis for end stage renal disease. American Journal Nephrology, 29, 36-42. doi: 10.1159/000150599.

Tomey, A.M., \& Alligood, M.R. (2006). Nursing theory: Utilization and aplication. (3 rd ed.). Missouri: Mosby Elsevier.

Tuncay, T. (2014). Coping and quality of life in turkish women living with ovarian cancer. Asian Pacific Journal Cancer Prevention, 15(9), 4005-4012. doi:http://dx.doi.org/10.7314/APJCP.2 014.15 .9 .4005 .

Ventegidt, M., \& Andersan. (2003). Quality of life theory I. the IQOL theory: an intergrative theory of global quality of life concept. Diakses dar. http://www. The Scientific Word.com pada tanggal 07 April 2018.

Wahl, et al. (1999). Coping and quality of life in patients with psoriasis, quality of life research, no. 8, hal: 427-33, (Online), http://springerlink.com., Diakses tanggal 16 Oktober 2011.

Wood, J.L., \& Heber, J. (2014). Nursing research methods and critical appraisal for evidance-based-practice. (8 th ed.). St.Louis: Mosby Elsevier.

Zachariah, L.M.S.\& Gopalkrishnan, S. (2014). Impact of music therapy during hemodialysis on selescted physiological paramaters of patients undergoing Hemodialysis in selected Hospitals. Interventional Journal of Comperhensive Nursing. Volume I. 